Vol 15, Issue 2, 2022

\title{
ANTIUROLITHIATIC ACTIVITY OF ETHANOLIC EXTRACT OF EICHHORNIA CRASSIPES (MART.) SOLMS WHOLE PLANT ON ETHYLENE GLYCOL-INDUCED UROLITHIASIS IN WISTAR RATS
}

\author{
REVATHI M*, INDUMATHY R \\ Department of Pharmacology, Institute of Pharmacology, Madras Medical College, Chennai, Tamil Nadu, India. Email: revathirace@gmail.com
}

Received: 20 February 2021, Revised and Accepted: 10 January 2022

\begin{abstract}
Objective: In India Indigenous system of medicine, the plant Eichhornia crassipes (Mart.) Solms is claimed to be useful for different ailments. The purpose of this study is to investigate the significant activity of the ethanolic extract of E. crassipes (Mart.) Solms whole plant in the treatment of renal stone by ethylene glycol (EG)-induced urolithiasis in Wistar rats.

Methods: Wistar rat will be divided into four groups. All the animals received EG 0.75\%v/v by orally for 28 days. Group I was received $0.75 \%$ v/v EG for 28 days. Groups II, III, and IV were received cystone, ethanolic extract of E. crassipes (Mart.) Solms (200 mg/kg, and $400 \mathrm{mg} / \mathrm{kg}$ ), respectively, administered orally from $15^{\text {th }}$ to $28^{\text {th }}$ day for curative regimen. Animals were housed in metabolic cages and collect the $24 \mathrm{~h}$ urine samples and serum samples on the $7^{\text {th }}, 14^{\text {th }}, 21^{\text {th }}$, and $28^{\text {th }}$ day of the experiments. Under the microscopical study to observe the crystals in urine sample. The biochemical parameters monitored in the present study are calcium, oxalate, magnesium, phosphorus, urea, creatinine, uric acid, blood urea nitrogen (BUN), and lactate dehydrogenase (LDH) in urine and serum samples.
\end{abstract}

Results: The EG feeding resulted in elevated renal excretion of calcium, phosphate, oxalate, and decreased renal excretion of magnesium as wellelevated serum BUN, creatinine, uric acid, urea, LDH levels, and decreased the urine $\mathrm{pH}$ and urine volume. Treatment of the ethanolic extract of $E$. crassipes (Mart.) Solms significantly reduced the elevated calcium, phosphate, oxalate in urine as well as BUN, creatinine, uric acid, urea, and LDH level in serum. It also restores the normal urine $\mathrm{pH}$ and promotes the urine output.

Conclusion: Ethanolic extract of E. crassipes (Mart.) Solms exhibited significant anti-urolithiatic activity evident from urine calcium, phosphate, oxalate levels and serum BUN, creatinine, uric acid, urea and LDH levels.

Keywords: Urolithiasis, Eichhornia crassipes (Mart.) Solms, Ethylene glycol, Urine volume.

(C) 2022 The Authors. Published by Innovare Academic Sciences Pvt Ltd. This is an open access article under the CC BY license (http://creativecommons.org/ licenses/by/4.0/) DOI: http://dx.doi.org/10.22159/ajpcr.2022v15i2.41176. Journal homepage: https://innovareacademics.in/journals/index.php/ajpcr

\section{INTRODUCTION}

Today urological practice, urinary stone continues to occupy an important place. Urinary stones mostly affect $10-12 \%$ of the population in industrialized countries. Epidemiological studies revealed that nephrolithiasis is highly present in men $(12 \%)$ than in women $(6 \%)$. Urinary stone is more prevalent between the ages of 20 and 40 in both sexes [1]. Especially, calcium-containing stones such as calcium oxalate monohydrate, calcium oxalate dihydrate and basic calcium phosphate are the most commonly occur ones to an extent of $75-90 \%$. Most commonly occurring stones are calcium oxalate or magnesium ammonium phosphate type [2]. Ethylene glycol (EG)-induced hyperoxaluria in animal model to use the experimental stone formation [3]. EG-induced kidney toxicity occurs within 24-72 h of post-ingestion. The glycolic acid is then metabolized to glyoxylic acid and finally to oxalic acid. Oxalic acid binds with calcium to form calcium oxalate crystals which may deposit in the kidney [4]. This can result in hematuria and proteinuria, increased creatinine, and renal failure [5]. Open surgical procedures for the treatment of ureteric stones have gradually disappeared in the past 30 years and have been replaced by minimal invasive techniques such as extracorporeal shock wave lithotripsy (ESWL) and ureteroscopy (URS). ESWL might show some significant side effects such as tissue damage to the kidney [6]. ESWL has been associated with long-term medical effects such as diabetes mellitus and hypertension. URS produced ureteric perforation and stricture formation remains around 2-4\% [7].

According to the WHO estimate, $80 \%$ of population living in the developing countries almost exclusively uses herbal medicines. Herbal medicines are in great demand in the developed world for primary health-care system. Herbal medicines are better compatible with human, because of their efficacy, safety, and lesser side effects. In India, Ayurvedic system of medicine "Pashanabheda" $($ Pashana = stone; Bheda = break $)$ group of plants break up the urinary stones and increase the urine output. This information on the present trends in research on plants accredited with antiurolithiatic activity [8]. Eichhornia crassipes (Mart.) Solms is a free-floating perennial aquatic plant (or hydrophyte), herbaceous monocotyledon member of the pickerelweed family (Pontederiaceae) is native to tropical and subtropical South America. The plant is locally known as "aahaya thamarai or vengaya thamarai." The nutritionally important compounds such as phenolic, flavonoids, alkaloid, sterols, terpenoids, glycosides, and many other metabolites have been isolated from different parts of E. crassipes (Mart.) Solms and possess various pharmacological activities such as sedative, central nervous system depressant, analgesic, anti-epileptic, antidepressant, memory enhancing agents, herbicidal, wound healing, anti-cancer, larvicidal, anti-inflammatory, immunostimulant, antibacterial, and cytotoxic activity. It can be used in agriculture as a fertilizer, feed, biomanure, and anti-diarrheal-induced urination [9 18]. The antiurolithiatic activity of the ethanolic extract of E. crassipes (Mart.) Solms whole plant on EGinduced urolithiasis in Wistar rats was evaluated presently.

\section{METHODS}

\section{Plant material}

The whole plant of E. crassipes was collected from their natural habitats in Kooduthurai River, Bhavani, Erode District, Tamil Nadu, in the month of August 2017. It was authenticated by Dr. K.N. Sunil Kumar. RO and HOD, Pharmacognosy, Siddha Central Research Institute, Arumbakkam, Chennai-600106, Tamil Nadu. 
Preparation of ethanolic extract

The whole plants of E. crassipes were cleaned and chopped into small pieces and dried under shade. The coarse powder of plant was obtained by mechanical grinding. The powdered material ( $40 \mathrm{~g}$ ) was subjected to continue hot extraction in Soxhlet apparatus at a temperature of $60-70^{\circ} \mathrm{C}$ using ethanol $(95 \% \mathrm{v} / \mathrm{v})$ as solvent. After complete extraction, the extract was dried. The extract was suspended in distilled water using $0.5 \%$ acacia as suspending agent for oral administration to animals [19].

\section{Experimental animals}

The present study was conducted as per CPCSEA/IAEC approval no: 1917/ReBi/S/16/CPCSEA/25.10.2016 and 5/AEL/IAEC/MMC, Date: 12.9.2017. The Wistar albino rats (150-200 g) used for this study were produced from Animal Experimental Laboratory, Madras Medical College, Chennai, India. The animals are kept in polypropylene cages (each cage contains six animals) under the standard laboratory condition (12 h light/dark cycle) and had free access to commercial pellet diet with water ad labium. The animal house temperature was maintained at $25 \pm 2^{\circ} \mathrm{C}$ with relative humidity at $50 \pm 15 \%$.

\section{Acute toxicity study [20]}

The acute toxicity study has been carried out already. The non-toxic nature of the ethanol extract of E. crassipes is evident from the acute oral toxicity conducted as per OECD guidelines (Organization of Economic Co-operation and development) 423 (Acute Toxic Class Method). The normal behavior of the test animals during a period of 14 days suggests the non-toxic nature of the extracts. Hence, E. crassipes should be safe up to the dose of $2000 \mathrm{mg} / \mathrm{kg}$ body weight of the animal.

\section{Pharmacological screening for antiurolithiatic activity $[21,22]$}

Animals were divided into four groups, each containing six animals. Groups I-IV animals were fed with $0.75 \%$ EG in water to induce renal calculi till the $28^{\text {th }}$ day. Group II animals were received standard antiurolithiatic drug cystone $\left(750 \mathrm{mg} / \mathrm{kg}\right.$ body weight) from $15^{\text {th }}$ to $28^{\text {th }}$ day. Groups III and IV animals served as curative regimen and received ethanolic extract of E. crassipes at a dose of $200 \mathrm{mg} / \mathrm{kg}$ and $400 \mathrm{mg} / \mathrm{kg}$ body weight from $15^{\text {th }}$ day to $28^{\text {th }}$ day. The extracts are administered once daily by oral route.

\section{Assessment of antiurolithiatic activity}

Collection and analysis of urine

Urine samples were collected on the $7^{\text {th }}, 14^{\text {th }}, 21^{\text {th }}$, and $28^{\text {th }}$ day for $24 \mathrm{~h}$ by keeping the animals in individual propylene metabolic cages. Animals have free access to drinking water during the urine collection period.
The collected urine was analyzed for calcium, oxalate, phosphate, and magnesium using standard methods. The volume of urine collected from all groups was recorded and urine $\mathrm{pH}$ was also recorded.

\section{Serum analysis}

After the experimental period, the blood was collected from the retro orbital puncture of rat eye under ether anesthesia. Serum was separated by centrifugation of the blood samples at 10,000 rpm for $10 \mathrm{~min}$ and analyzed for creatinine, uric acid, urea, and blood urea nitrogen (BUN) using standard methods.

\section{Statistical analysis [19]}

Results were expressed as Mean \pm Standard Error of Mean (SEM). p $<0.05$ was considered as statistically significant. Data obtained were analyzed by one-way analysis of variance (ANOVA) followed by Dunnett's multiple comparisons test using GraphPad Prism version 7.

\section{RESULTS AND DISCUSSION}

In the present study, chronic induction of EG $(0.75 \% \mathrm{v} / \mathrm{v})$ to Wistar rats were resulted significant $(\mathrm{p} \leq 0.0001)$ increase in the $7^{\text {th }}$ and $14^{\text {th }}$ day of urinary excretion of calcium, phosphate, and oxalate and reduction of magnesium levels in Groups I, II, III, and IV rats. On day 21 and 28, whereas the cystone-treated Group II animals were shown significant $(p \leq 0.0001)$ reduction in calcium, phosphate, and oxalate and increase magnesium levels in urine. Similarly, treatment with ethanolic extract of E. crassipes whole plant at the dose of $200 \mathrm{mg} / \mathrm{kg}$ and $400 \mathrm{mg} / \mathrm{kg}$ was administered for Groups III and IV, respectively, and then significant $(p \leq 0.0001)$ lowered the elevated levels of calcium, oxalate, phosphate, and increase magnesium level in urine, when curative regimens compared to EG-induced Group I animals (Table 1 and Figs. 1-4).

On the day 7 and 14, urine volume and $\mathrm{pH}$ were significantly $(\mathrm{p} \leq 0.0001)$ reduced in Groups I, II, III, and IV animals, while the urine volume and $\mathrm{pH}$ were significantly $(\mathrm{p} \leq 0.0001)$ increase in cystone-treated Group II animals. However, on days 21 and 28, urine volume and $\mathrm{pH}$ were significantly $(\mathrm{p} \leq 0.0001)$ increased in curative regimen groups (III and IV). However, on days 21 and 28, urine volume and $\mathrm{pH}$ were significantly $(\mathrm{p} \leq 0.0001)$ increased in curative regimen groups (III and IV) when compared to EG-induced Group I animals (Table 2, Figs. 5 and 6).

On the day 7 and 14, BUN, serum creatinine, urea, uric acid levels, and lactate dehydrogenase (LDH) level were significantly $(\mathrm{p} \leq 0.0001)$

Table1: Estimation of calcium, oxalate, phosphate, and magnesium in urine

\begin{tabular}{|c|c|c|c|c|c|c|}
\hline \multirow[t]{4}{*}{ Urine parameters $(\mathrm{mg} / \mathrm{dl})$} & \multirow[t]{4}{*}{ Group } & \multicolumn{5}{|c|}{ Ethylene glycol induction } \\
\hline & & \multirow{3}{*}{$\begin{array}{l}\text { Before } \\
0^{\text {th }} \text { day }\end{array}$} & \multicolumn{4}{|l|}{ After } \\
\hline & & & \multirow[t]{2}{*}{$7^{\text {th }}$ day } & \multicolumn{3}{|c|}{ Curative regimens } \\
\hline & & & & $14^{\text {th }}$ day & $21^{\text {th }}$ day & $28^{\text {th }}$ day \\
\hline \multirow[t]{3}{*}{ Calcium } & Disease control & $7.66 \pm 0.22$ & $8.18 \pm 0.24$ & $8.61 \pm 0.33$ & $9.02 \pm 0.13$ & $11.13 \pm 0.36$ \\
\hline & Standard & $8.18 \pm 0.24$ & $8.73 \pm 0.04^{*}$ & $9.02 \pm 0.14^{\mathrm{ns}}$ & $8.52 \pm 0.04^{*}$ & $8.16 \pm 0.06^{* * * *}$ \\
\hline & High dose & $7.22 \pm 0.06$ & $8.04 \pm 0.16^{\mathrm{ns}}$ & $8.43 \pm 0.10^{\mathrm{ns}}$ & $8.32 \pm 0.16^{* * * *}$ & $7.78 \pm 0.08^{* * * *}$ \\
\hline \multirow[t]{4}{*}{ Oxalate } & Disease control & $1.36 \pm 0.05$ & $2.20 \pm 0.25$ & $3.03 \pm 0.07$ & $4.41 \pm 0.06$ & $5.35 \pm 0.05$ \\
\hline & Standard & $1.57 \pm 0.12$ & $2.35 \pm 0.19^{\text {ns }}$ & $2.59 \pm 0.28^{\mathrm{ns}}$ & $2.15 \pm 0.23^{* * * *}$ & $1.88 \pm 0.20^{* * * *}$ \\
\hline & Low dose & $1.46 \pm 0.08$ & $1.86 \pm 0.07^{\mathrm{ns}}$ & $2.05 \pm 0.06^{* * *}$ & $1.74 \pm 0.07^{* * * *}$ & $1.43 \pm 0.06^{* * * *}$ \\
\hline & High dose & $1.55 \pm 0.06$ & $1.94 \pm 0.08^{\mathrm{ns}}$ & $2.13 \pm 0.11^{* *}$ & $1.82 \pm 0.08^{* * * *}$ & $1.62 \pm 0.09^{* * * *}$ \\
\hline \multirow[t]{3}{*}{ Phosphate } & Disease control & $4.87 \pm 0.14$ & $6.16 \pm 0.13$ & $7.22 \pm 0.18$ & $7.96 \pm 0.10$ & $8.46 \pm 0.11$ \\
\hline & Standard & $4.4 \pm 0.15$ & $4.93 \pm 0.07^{* * * *}$ & $5.34 \pm 0.09 * * * *$ & $4.83 \pm 0.06^{* * * *}$ & $4.46 \pm 0.08^{* * * *}$ \\
\hline & Low dose & $4.4 \pm 0.12$ & $4.90 \pm 0.14^{* * * *}$ & $5.23 \pm 0.09 * * * *$ & $4.95 \pm 0.07^{* * * *}$ & $4.65 \pm 0.10^{* * * *}$ \\
\hline \multirow[t]{4}{*}{ Magnesium } & Disease control & $3.07 \pm 0.01$ & $2.97 \pm 0.01$ & $2.88 \pm 0.01$ & $2.66 \pm 0.05$ & $1.75 \pm 0.04$ \\
\hline & Standard & $3.06 \pm 0.01$ & $2.89 \pm 0.01^{* * * *}$ & $2.66 \pm 0.05^{* * * *}$ & $2.79 \pm 0.02 *$ & $2.86 \pm 0.03^{* * * *}$ \\
\hline & Low dose & $3.08 \pm 0.01$ & $2.97 \pm 0.01^{\text {ns }}$ & $2.88 \pm 0.01^{\mathrm{ns}}$ & $2.9 \pm 0.01^{* * * *}$ & $2.94 \pm 0.02^{* * * *}$ \\
\hline & High dose & $3.08 \pm 0.01$ & $2.98 \pm 0.01^{\mathrm{ns}}$ & $2.79 \pm 0.02 *$ & $2.94 \pm 0.02^{* * * *}$ & $3.02 \pm 0.02^{* * * *}$ \\
\hline
\end{tabular}

Values were expressed as Mean \pm SEM, $n=6$. Comparisons were made between: Group-I versus Group II, Group-III, and Group- IV. The data were statistically analyzed by one-way ANOVA, followed by Dunnett's multiple comparison test. $P$ values ${ }^{* * * *} \mathrm{p} \leq 0.0001,{ }^{* * *} \mathrm{p} \leq 0.001,{ }^{* *} \mathrm{p} \leq 0.01$, and ${ }^{*} \mathrm{p} \leq 0.05$. ns: Non-significant-p $>0.05$ 
Table 2: Estimation of $\mathrm{pH}$ and volume in urine

\begin{tabular}{|c|c|c|c|c|c|c|}
\hline \multirow[t]{4}{*}{ Parameters } & \multirow[t]{4}{*}{ Group } & \multicolumn{5}{|c|}{ Ethylene glycol induction } \\
\hline & & \multirow{3}{*}{$\begin{array}{l}\text { Before } \\
0^{\text {th }} \text { day }\end{array}$} & \multicolumn{4}{|l|}{ After } \\
\hline & & & \multirow[t]{2}{*}{$7^{\text {th }}$ day } & \multicolumn{3}{|c|}{ Curative regimens } \\
\hline & & & & $14^{\text {th }}$ day & $21^{\text {th }}$ day & $28^{\text {th }}$ day \\
\hline \multirow[t]{4}{*}{ Urine volume $(\mathrm{ml})$} & Disease control & $2.53 \pm 0.19$ & $2.38 \pm 0.21$ & $2.06 \pm 0.17$ & $1.67 \pm 0.16$ & $1.25 \pm 0.22$ \\
\hline & Standard & $2.38 \pm 0.05$ & $2.20 \pm 0.12^{\mathrm{ns}}$ & $1.96 \pm 0.09^{\mathrm{ns}}$ & $5.23 \pm 0.19^{* * * *}$ & $5.67 \pm 0.16^{* * * *}$ \\
\hline & Low dose & $2.35 \pm 0.04$ & $2.33 \pm 0.07^{\mathrm{ns}}$ & $2.16 \pm 0.10^{\mathrm{ns}}$ & $4.75 \pm 0.20^{* * * *}$ & $5.21 \pm 0.03^{* * * *}$ \\
\hline & High dose & $2.55 \pm 0.31$ & $2.36 \pm 0.08^{\mathrm{ns}}$ & $1.96 \pm 0.08^{\mathrm{ns}}$ & $5.98 \pm 0.18^{* * * *}$ & $6.23 \pm 0.15^{* * * *}$ \\
\hline \multirow[t]{4}{*}{ Urine $\mathrm{pH}$} & Disease control & $7.18 \pm 0.03$ & $6.82 \pm 0.16$ & $6.63 \pm 0.08$ & $6.5 \pm 0.07$ & $6.47 \pm 0.08$ \\
\hline & Standard & $7.15 \pm 0.02$ & $6.97 \pm 0.20^{\text {ns }}$ & $6.9 \pm 0.11^{\mathrm{ns}}$ & $7.27 \pm 0.08^{* * * *}$ & $7.13 \pm 0.07^{* * * *}$ \\
\hline & Low dose & $7.23 \pm 0.02$ & $7.03 \pm 0.08^{\text {ns }}$ & $7.17 \pm 0.08^{*}$ & $7.25 \pm 0.03^{* * * *}$ & $7.2 \pm 0.04^{* * * *}$ \\
\hline & High dose & $7.25 \pm 0.03$ & $7.08 \pm 0.16^{\mathrm{ns}}$ & $6.73 \pm 0.16^{\mathrm{ns}}$ & $7.23 \pm 0.06^{* * * *}$ & $7.33 \pm 0.02^{* * * *}$ \\
\hline
\end{tabular}

by one-way ANOVA, followed by Dunnett's multiple comparison test. $P$ values ${ }^{* * * *} \mathrm{p} \leq 0.0001{ }^{* * *} \mathrm{p} \leq 0.001,{ }^{* *} \mathrm{p} \leq 0.01$, and ${ }^{*} \mathrm{p} \leq 0.05$. ns: Non-significant-p $>0.05$

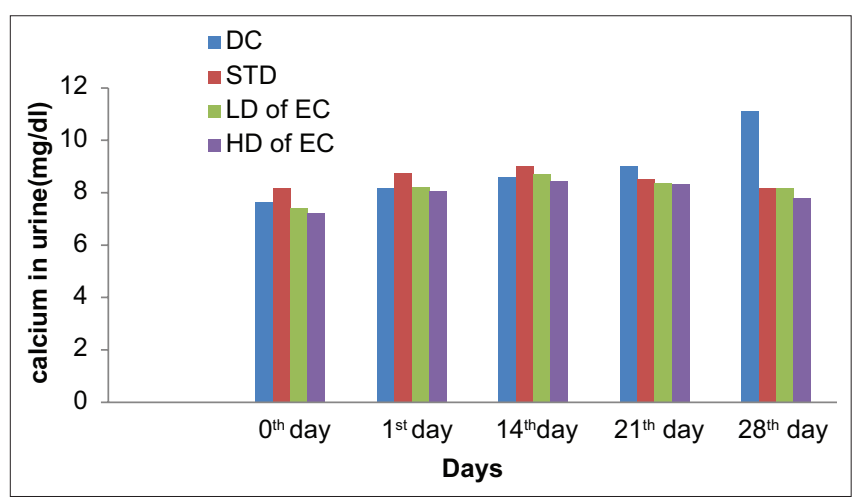

Fig. 1: Estimation of calcium in urine

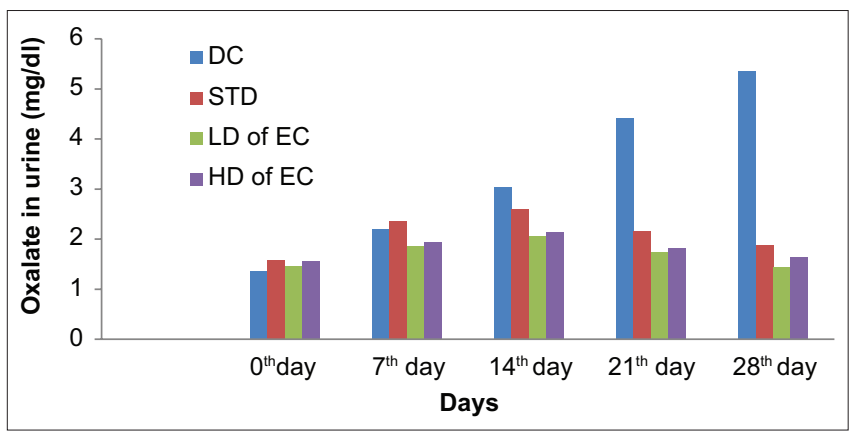

Fig. 2: Estimation of oxalate in urine

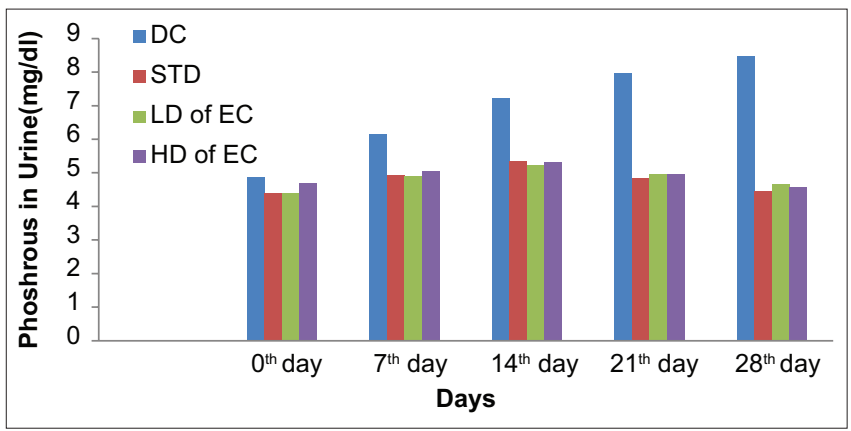

Fig. 3: Estimation of phosphate in urine

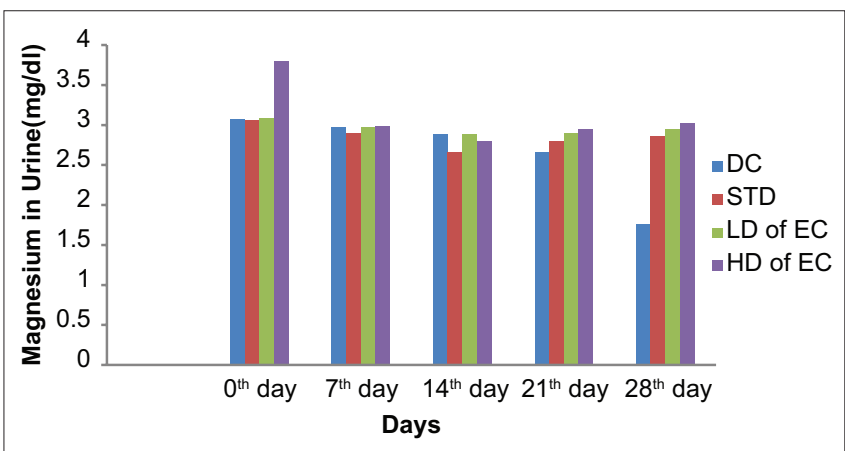

Fig. 4: Estimation of magnesium in urine

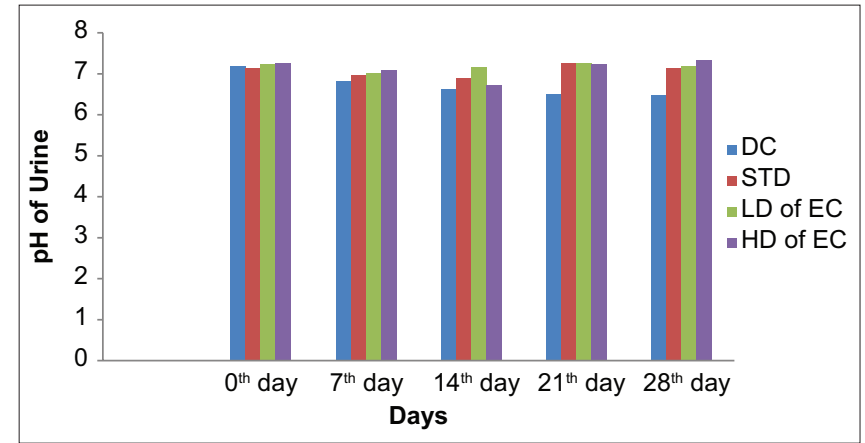

Fig. 5: Estimation of pH

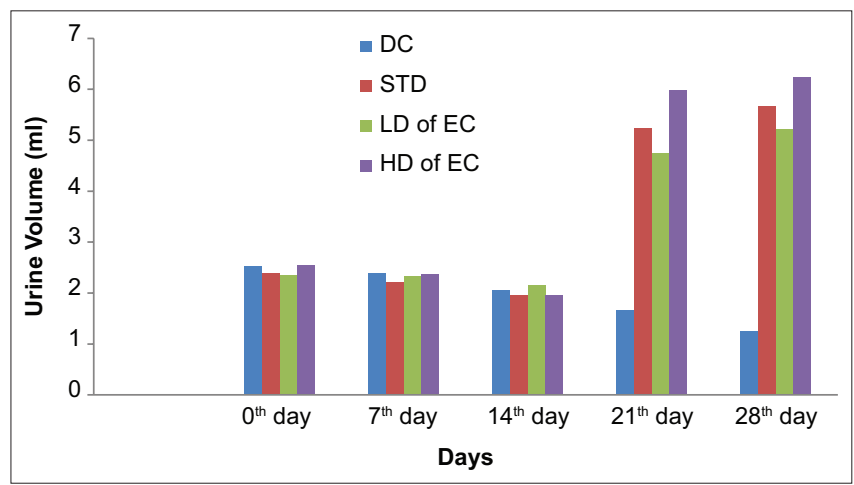

Fig. 6: Estimation of urine volume 
Table 3: Estimation of serum urea, uric acid, creatinine, and BUN

\begin{tabular}{|c|c|c|c|c|c|c|}
\hline \multirow[t]{4}{*}{ Serum parameters $(\mathrm{mg} / \mathrm{dl})$} & \multirow[t]{4}{*}{ Group } & \multicolumn{5}{|c|}{ Ethylene glycol induction } \\
\hline & & \multirow{3}{*}{$\begin{array}{l}\text { Before } \\
0^{\text {th }} \text { day }\end{array}$} & \multicolumn{4}{|l|}{ After } \\
\hline & & & \multirow[t]{2}{*}{$7^{\text {th }}$ day } & \multicolumn{3}{|c|}{ Curative regimens } \\
\hline & & & & $14^{\text {th }}$ day & $21^{\text {th }}$ day & $28^{\text {th }}$ day \\
\hline \multirow[t]{3}{*}{ Urea } & Disease control & $9.51 \pm 0.12$ & $10.21 \pm 0.07$ & $11.54 \pm 0.25$ & $13.57 \pm 0.26$ & $15.05 \pm 0.14$ \\
\hline & Standard & $9.74 \pm 0.21$ & $10.04 \pm 0.21^{\mathrm{ns}}$ & $10.95 \pm 0.18^{* * *}$ & $10.39 \pm 0.19 * * * *$ & $9.90 \pm 0.12^{* * * *}$ \\
\hline & High dose & $9.64 \pm 0.10$ & $9.97 \pm 0.07^{\mathrm{ns}}$ & $10.13 \pm 0.04^{* * * *}$ & $9.9 \pm 0.047 * * * *$ & $9.5 \pm 0.14 * * * *$ \\
\hline \multirow[t]{4}{*}{ Uric acid } & Disease control & $2.40 \pm 0.03$ & $2.87 \pm 0.03$ & $3.13 \pm 0.03$ & $3.54 \pm 0.07$ & $4.14 \pm 0.19$ \\
\hline & Standard & $2.39 \pm 0.06$ & $2.57 \pm 0.06^{* *}$ & $2.82 \pm 0.04^{* * * *}$ & $2.56 \pm 0.04^{* * * *}$ & $2.32 \pm 0.04^{* * * *}$ \\
\hline & Low dose & $2.47 \pm 0.08$ & $2.77 \pm 0.03^{\mathrm{ns}}$ & $3.07 \pm 0.05^{\mathrm{ns}}$ & $2.85 \pm 0.08^{* * * *}$ & $2.48 \pm 0.06^{* * * *}$ \\
\hline & High dose & $2.46 \pm 0.03$ & $2.81 \pm 0.03^{\mathrm{ns}}$ & $3.19 \pm 0.01^{\mathrm{ns}}$ & $2.98 \pm 0.05^{* * * *}$ & $2.58 \pm 0.08^{* * * *}$ \\
\hline \multirow[t]{3}{*}{ Creatinine } & Disease control & $0.59 \pm 0.02$ & $0.66 \pm 0.01$ & $0.72 \pm 0.01$ & $0.75 \pm 0.01$ & $0.77 \pm 0.01$ \\
\hline & Standard & $0.64 \pm 0.01$ & $0.64 \pm 0.01^{\mathrm{ns}}$ & $0.68 \pm 0.01^{\mathrm{ns}}$ & $0.61 \pm 0.06^{* * * *}$ & $0.54 \pm 0.01^{* * * *}$ \\
\hline & Low dose & $0.57 \pm 0.01$ & $0.60 \pm 0.01^{* *}$ & $0.63 \pm 0.01^{* * *}$ & $0.59 \pm 0.01^{* * * *}$ & $0.53 \pm 0.01^{* * * *}$ \\
\hline \multirow{3}{*}{ BUN } & Standard & $4.4 \pm 0.15$ & $4.93 \pm 0.07 * * * *$ & $5.34 \pm 0.09 * * * *$ & $4.83 \pm 0.06^{* * * *}$ & $4.46 \pm 0.08^{* * * *}$ \\
\hline & Low dose & $4.4 \pm 0.12$ & $4.90 \pm 0.14^{* * * *}$ & $5.23 \pm 0.09 * * * *$ & $4.95 \pm 0.07 * * * *$ & $4.65 \pm 0.10^{* * * *}$ \\
\hline & High dose & $4.67 \pm 0.19$ & $5.05 \pm 0.14^{* * * *}$ & $5.31 \pm 0.14^{* * * *}$ & $4.96 \pm 0.13^{* * * *}$ & $4.58 \pm 0.15^{* * * *}$ \\
\hline
\end{tabular}
one-way ANOVA, followed by Dunnett's multiple comparison test. $P$ values ${ }^{* * *} \mathrm{p} \leq 0.0001,{ }^{* * *} \mathrm{p} \leq 0.001,{ }^{* *} \mathrm{p} \leq 0.01$, and ${ }^{*} \mathrm{p} \leq 0.05$. ns: Non-significant)-p $>0.05$, BUN: Blood urea nitrogen

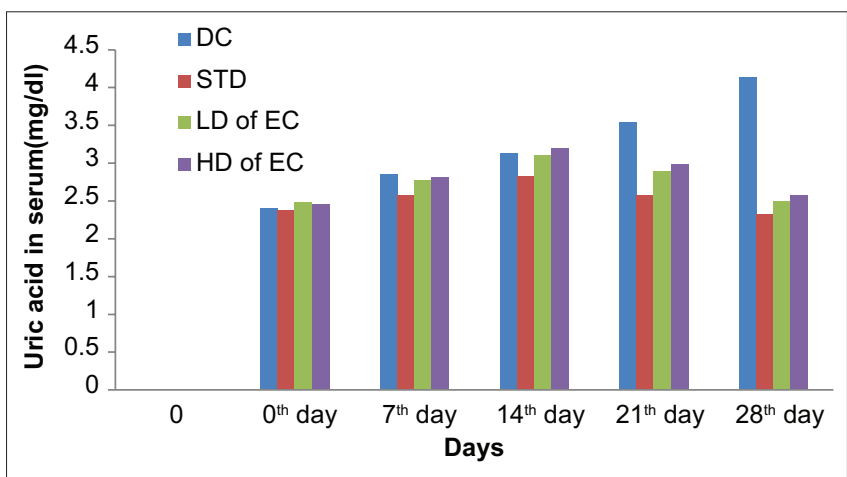

Fig. 7: Estimation of serum uric acid

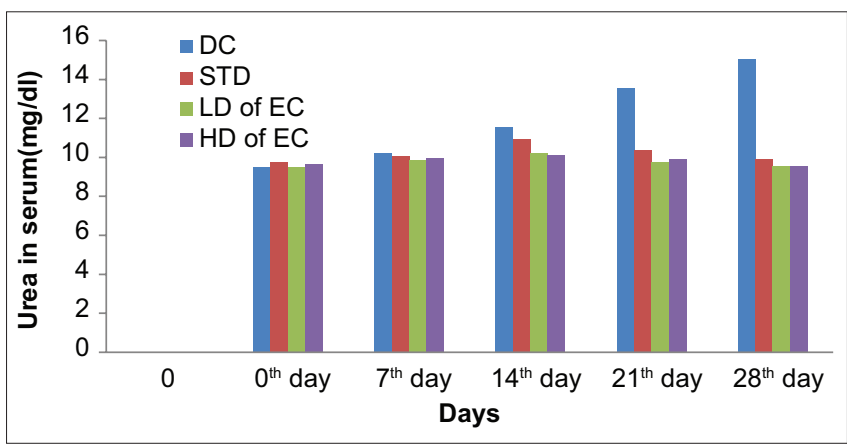

Fig. 8: Estimation of serum urea

increased in Groups I, II, III, and IV animals. On the day 7 and 14, BUN, serum creatinine, urea, uric acid levels and lactate dehydrogenase (LDH) level were significantly ( $\mathrm{p} \leq 0.0001)$ increased in Groups I, II, III, and IV animals, while the BUN, serum creatinine, uric acid, urea and lactate dehydrogenase (LDH) levels were significantly $(\mathrm{p} \leq 0.0001)$ decreased in cystone-treated Group II animals.. However, on days 21

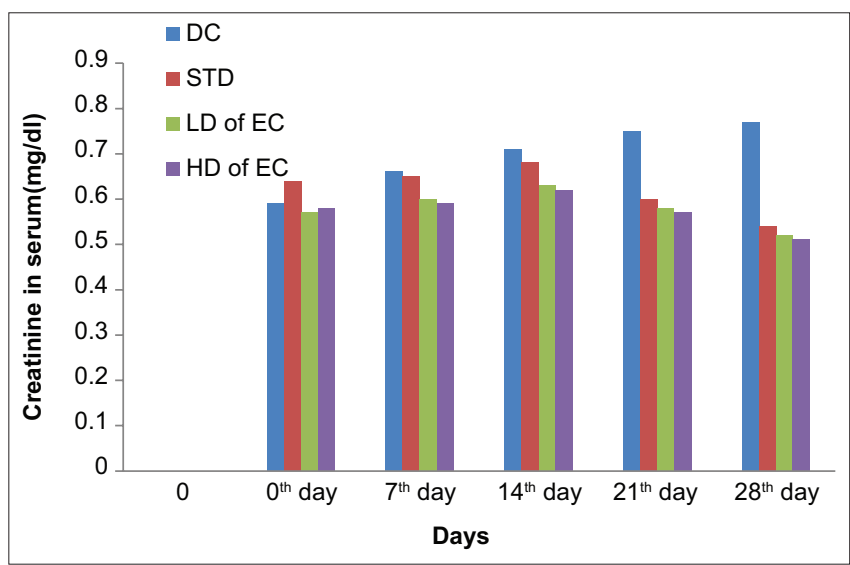

Fig. 9: Estimation of serum creatinine

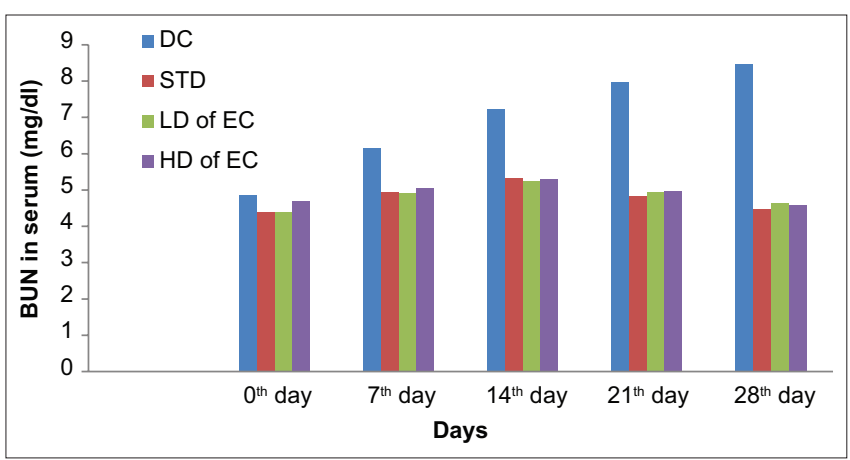

Fig. 10: Estimation of serum blood urea nitrogen

and 28, the BUN, serum creatinine, urea, uric acid levels, and LDH level were significantly $(\mathrm{p} \leq 0.0001)$ decreased in curative regimen groups (III and IV). However, on days 21 and 28, the BUN, serum creatinine, urea, uric acid levels, and LDH level were significantly $(\mathrm{p} \leq 0.0001)$ decreased in curative regimen groups (III and IV) when compared to EG-induced Group I animals (Tables 3 and 4, Figs. 7-11). 
Table 4: Estimation of serum LDH

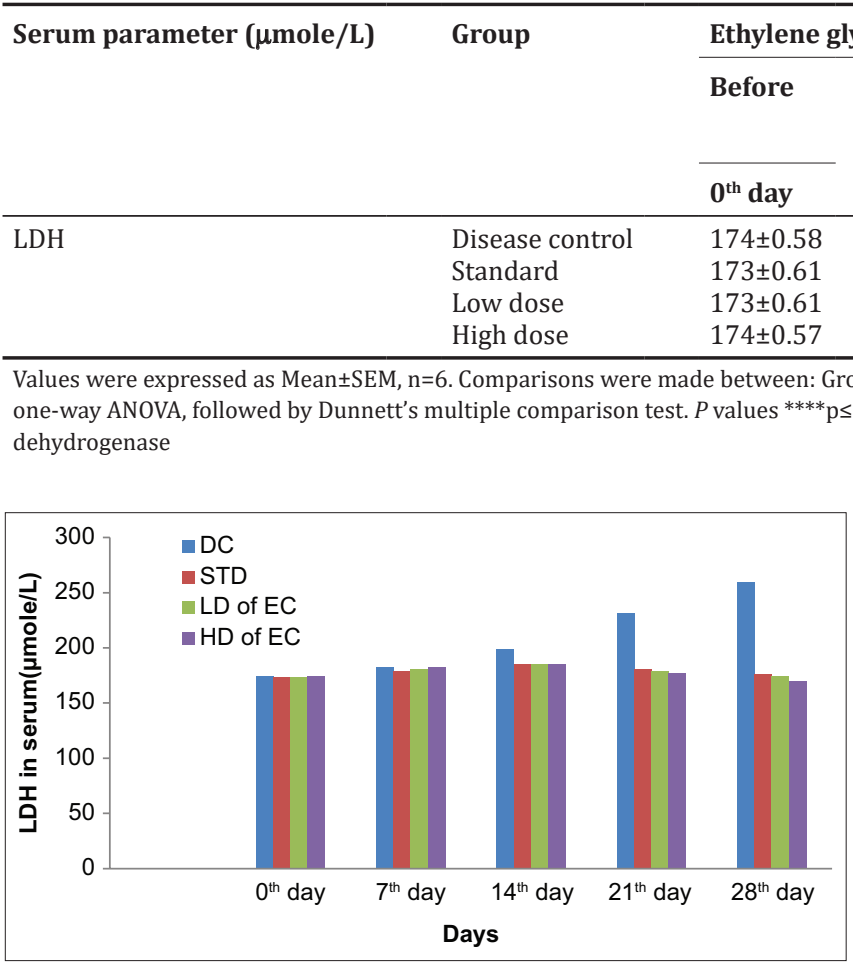

Fig. 11: Estimation of serum lactate dehydrogenase

\section{CONCLUSION}

The study was revealed that the ethanolic extract of E. crassipes (Mart.) Solms whole plant was found to possessed potent antiurolithiatic activity. However, further evaluation of the mechanism of action of isolated compound from this plant and clinical trials may yield a solution for this urinary problem.

\section{REFERENCES}

1. Butterweck V, Khan SR. Herbal medicines in the management of urolithiasis: Alternative or complementary? Planta Med 2009; 75:1095-103

2. Yadav RD, Jain SK, Alok S, Mahor A, Bharti JP, Jaiswal M. Herbal plants used in the treatment of urolithiasis: A review. Int J Pharm Sci Res 2011;2:1412-20

3. Jarald EE, Kushwah P, Edwin S, Asghar S, Patni SA. Effect of unex on ethylene glycol-induced urolithiasis in rats. Indian J Pharmacol 2011;43:466-8.

4. Ethylene Glycol Poisoning. Pathophysiology. Available from: https:// www.en.wikipedia.org/wiki/Ethylene glycol poisoning

5. Rao NR, Preminger GM, Kavanagh JP. Urinary Tract Stone Disease. New York: Springer-Verlag London Limited; 2011. p. 383-8.

6. Siroky MB, Edelstein RS, Krane RJ. Manual of Urology. Diagnosis and Therapy. $2^{\text {nd }}$ ed. Washington, DC: Lippincott Williams and Wilkins;
1999. p. 136.

7. Salam MA. Principles and Practice of Urology. $2^{\text {nd }}$ ed., Vol. 2. New Delhi: Jaypee Brothers Medical Publishers (P) Ltd.; 2013. p. 564.

8. Dhole AR, Yeligar VC. Urolithiasis and Its Herbal Remedies. Int J S Res Sci Technol 2018;4:150-6.

9. Water Hyacinth. Available from: https://www.researchgate.net/ publication/278306432_Water_Hyacinth

10. Mahmood Q, Zheng P, Siddiqi MR, ul Islam E, Azim MR, Hayat Y. Anatomical studies on water hyacinth (Eichhornia crassipes (Mart.) Solms) under the influence of textile waste water. J Zhejiang Univ Sci B 2005;6:991-8

11. Malik A. Environmental challenge vis a vis opportunity: The case of water hyacinth. Environ Int 2007;33:122-38.

12. Jayanthi P. Phytochemical investigation of the extracts of Eichhornia crassipes and its solvent fractionates. J Pharm Res 2011;4:1405-6.

13. Lalitha P, Sripathi SK, Jayanthi P. Secondary metabolites of Eichhornia crassipes (water hyacinth): A review (1949 to 2011). Nat Prod Commun 2012;7:1249-59.

14. Tulika T, Mala A. Pharmaceutical potential of aquatic plant Pistia stratiotes (L.) and Eichhornia crassipes. J Plant Sci 2015;3:10-8.

15. Abdel-Sabour MF. Water hyacinth: Available and renewable resource. Elec J Environ Agric Food Chem 2010;9:1746-59.

16. Rorong JA, Sudiarso S, Prasetya B, Polii-Mandang J, Suryanto E. Phytochemical analysis of water hyacinth (Eichhornia crassipes) of agricultural waste as bio sensitizer for ferri photo reduction. Agrivita 2012;34:152-60.

17. Shah R, Islam M, Rabbi F, Shova NA, Akter A, Akter H, et al. Phytotherapeutic Practices of a folk medicinal practitioner in Dinajpur district, Bangladesh. J App Pharm Sci 2017;7:161-5.

18. Medicinal uses of Eichhornia crassipes. Available from: https://www. plants.usda.gov/uses

19. Chinnala KM, Shanigarm S, Elsani MM. Antiuolithiatic activity of the plant extracts of Solanum virginianumon Ethylene glycol induced urolithiasis in rats. Int J Pharm Biol Sci 2013;3:328-34.

20. Lalitha P, Sripathi SK, Jayanthi P. Acute toxicity study of extracts of Eichhornia Crassipes (MART.) SOLMS. Asian J Pharm Clin Res 2012;5:59-61

21. Bahuguna Y, Rawat MS, Juyal V, Gupta V. Antilithiatic effect of flowers of Jasminum auriculatum Vahl. Int J Green Pharm 2009;3:155-8.

22. Betanabhatla K, Christina AJ, Sundar BS, Kumar SS, Saravanan KS. Antilithiatic activity of Hibiscus sabdariffa. Linn. On ethylene glycol induced lithiasis in rats. Nat Prod Radiance 2009;8:43-7. 